\title{
Geographic range expansion of Leucotmemis pardalimacula Dyar, 1927 (Lepidoptera: Erebidae: Arctinae: Euchromiina) with notes about its conservation in Mexico
}

\author{
Fernando Hernández-Baz ${ }^{1}$ *, Jorge M. GonzÁlez ${ }^{2}$ and Manuel Balcázar Lara ${ }^{3}$ \\ ${ }^{1}$ Facultad de Biología-Xalapa, Universidad Veracruzana, Zona Universitaria, Circui- \\ to Gonzalo Aguirre Beltrán, s/n, C.P. 91000, Xalapa, Veracruz, México \\ ${ }^{2}$ California State University, Fresno, Department of Plant Sciences, Fresno, \\ California 93740-8033 (Research Associate, McGuire Center for Lepidoptera \& \\ Biodiversity), U.S.A. \\ E-mail: gonzalez.jorge.m@gmail.com \\ ${ }^{3}$ Facultad de Ciencias Biológicas y Agropecuarias, Universidad de Colima, Auto- \\ pista Colima-Manzanillo km 40, 28930, Tecomán, Colima, México \\ E-mail:mabl@ucol.mx \\ *Corresponding author. E-mail: fhernandez@uv.mx; ferhbmx@yahoo.com.mx
}

\begin{abstract}
Information about the geographical distribution of Leucotmemis pardalimacula is updated after reviewing data gathered from its description in 1927 to 2010. This species is known to live in the mountainous zones of Western Mexico and its distribution spreads south down to the Chinandega volcanic zone in Nicaragua. Based on previously developed methods, the vulnerability of this moth wasp is evaluated herein. The species could be categorized as "threatened" according to the Mexican Conservation Norm NOM-059, allowing us to propose the taxon to be included under the Official Mexican Norm of Protection.
\end{abstract}

Key Words. Biogeography, wasp moths, Biological conservation, Nicaragua

\section{INTRODUCTION}

The order Lepidoptera in Mexico is represented by 32 families containing 14,385 recorded species (Heppner 2002). However, despite the richness of butterflies and moths, the order is poorly known except for species in the Papilionoidea (Hernández-Baz 2012).

Wasp moths are currently included in the Noctuoidea: Erebidae: Arctiinae: Arctiini and have been divided into two subtribes: Ctenuchina and Euchromiina (Lafontaine \& Fibinger 2006, Lafontaine \& Schmidt 2010). These species typically fly during the day, although many species are frequently captured at lights (Hernández-Baz \& Bailey 2006, Hernández-Baz et al. 2013).

Wasp moths are mainly distributed in the Neotropics (Hernández-Baz 2012) with species richness reaching some 2,532 species; 2,475 being exclusively Neotropical (Heppner 1991) while only 36 are Neartic (Lafontaine \& Schmidt 2010). More recently, some authors have suggested that the total number of species might approach 3,000 (Simmons et al. 2012). There are 240 species of the group known from Mexico (Hernández-Baz et al. 2012, 2013), with 128 in 39 genera of Ctenuchina, the remaining 112 species within 31 genera of Euchromiina, and ten endemics (Hernández-Baz 1992, 2008, 2009, 2010, 2011a, 2011b, 2013; Hernández-Baz et al. 2012, 2013).

The genus Leucotmemis Butler, 1876 contains 27 species (Bisby et al. 2011). It was described based on a specimen of L. latilinea (Walker, 1854) [= Glaucopis (Ilipa) latilinea Walker, 1854], collected in Brazil by Henry Bates. Two species, L. nexa (Herrich-Schäffer, 1854) and L. pardalimacula Dyar, 1927, have been reported from Mexico (Hernández-Baz 2012). 
Many species of flora and fauna from Mexico are protected by the Official Mexican Norm for environmental protection NOM-059: "Native species of flora and fauna of Mexico - Risk categories and specifications for inclusion, exclusion and change List of species under risk" (Semarnat 2010). However, contrary to the high Mexican richness (sensu Heppner 2002), only two Lepidoptera species are under official protection: Papilio esperanza (Beutelspacher, 1975) (Papilionidae), which is endemic of Mexico and, Danaus plexippus plexippus (Linnaeus, 1758) (Nymphalidae), a migratory species. Recent efforts seek to include three wasp moths for official protection in México, Apeplopoda mecrida (Druce, 1889) (Hernández-Baz 2012a), Coreura albicosta Draudt, 1916 (Hernández-Baz et al. 2012b), and Scena propylea (Druce, 1894) (Hernández-Baz et al. 2013)

The main aim of this study is to present detailed geographic distribution and conservation information about the species $L$. pardalimacula in order to be considered in the Mexican Official Norm NOM-059.

\section{Methods AND Materials}

The information presented herein comes mainly from three sources: a) specimens collected by the first author (FHB) and deposited in the collection: SEMARNAT/CITES/ CP-0026-VER/05 (as codified by Secretaría del Medio Ambiente y Recursos Naturales of the Government of México), Xalapa, Veracruz, Mexico (CPFHB); b) review of five institutional collections: Natural History Museum of the City of Mexico (MHNCM), National Collection of Insects, Biology Institute of the National University of Mexico (CNIIBUNAM), Natural History Museum, London, UK (BMNH), Lepidoptera Collection of the University of Colima (UCOL), and the entomological collection of the College of the Southern Border, Chiapas (ECO-SC-E); and c) review of literature, with particular emphasis on Dyar (1927) and Hernández-Baz (2012).

All records (data from bibliographic and collection sources) were organized in an Excel spread sheet. Locality georeferencing was based on the INEGI catalogue of names and the 1:250000 topographic map of Mexico 1:250 edited by the Mexican National Institute of Statistics, Geography and Computer science (INEGI 2012). Localities from the "Polilla" database were transformed into sexagesimal data for inclusion in a geographical information system for the Arc view 2.0 program (ESRI 1998).

The following criteria, previously established for other closely related species by Hernández-Baz (2012), were used to determine the priority of conservation of L. pardalimacula. They consider the usage of six different variables: 1) Continental Geographic Distribution (CGD), 2) Endemicity (E), 3) Habitat Specificity (HS), 4) Persistence (P), 5) Rarity (R), and 6) Extractive Actions (EA). Every variable was ranked hierarchically using a numerical value from 0 to 3 . Once the hierarchies for every variable were added, levels or categories were obtained: Lack of Information (0-3), Low (4-8), Medium (9-13), High (14-17) and Extreme (18). The obtained value was added to the species, as well as its equivalent value of the NOM-059 (Semarnat 2010) established by the Secretary of Environmental and Natural Resources and Fisheries of Mexico.

\section{REsults AND Discussion}

Geographic Distribution. Leucotmemis pardalimacula (Figure 1) was described based on two female specimens collected in Colima City, Mexico. After reviewing all available literature on the species and the collections studied, only 10 specimens of 


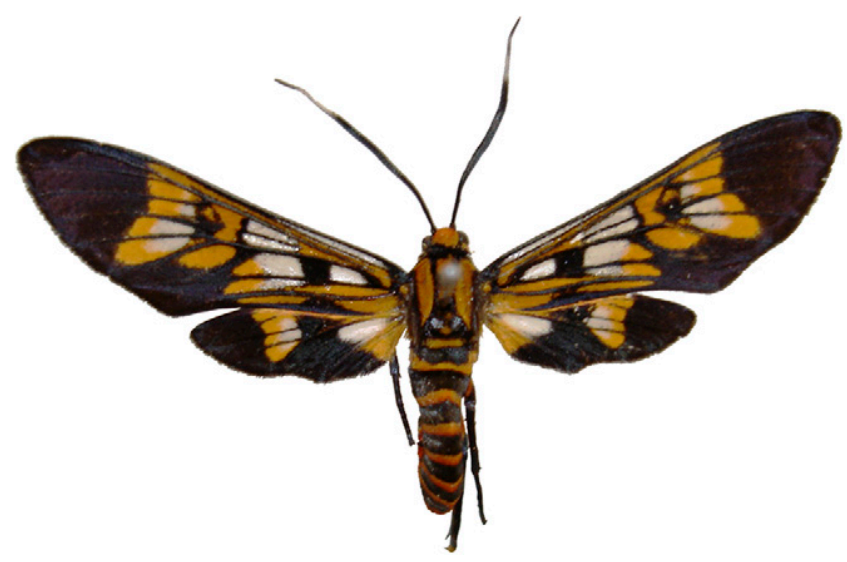

Figure 1. Leucotmemis pardalimacula specimen deposited at Insect Collection of the Biology Institute of the National University of Mexico, UNAM. Photo by F. Hernández-Baz.

the taxon were found. They were also included in the "polilla" database, which is an annex of the SEMARNAT/CITES/CP-0026-VER/05 collection in Xalapa, Veracruz, Mexico.

Material Reported and Examined. México: Jalisco: 2 f\#f\#, Chamela, 234m, v-1975, vii-1976, N19²9'15'//10459'42"', C.R. Beutelspacher, (CNIIBUNAM); 1m\#, viii-1977, A. Pescador; 1m\#, Colima, Villa de Alvarez, Zacualpan $1.5 \mathrm{~km}$ al SW, 683m, 16-X-2004, N19 21'30" //103 5015 O., M. Balcazar L. (UCOL-019054); Colima: Colima, Col. (Hernández-Baz, 1992); GUERRERO: CHILPANCINGO, Acahuizotla, 900m, 19-ii-1980, N17²1'36"'//99²8'00"', (MAZA P080, CONABIO);

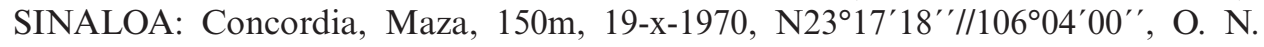
Hancock; (MAZA P080, CONABIO); Puerto Mazatlán 5k N. 70m, 27-vii-1973, 1-viii1973, N2316'50' $/ / 106^{\circ} 25^{\prime} 12^{\prime \prime}$, E. Giesbert, (Maza P080, CONABIO); Nicaragua: Chinandega: Entre el volcán San Cristobal y el Volcán Choco, 1m\#, 696m, 30-x-2004, N12 $42^{\prime} 17.23^{\prime \prime} / / 87^{\circ} 01^{\prime} 44.95^{\prime \prime}$, F. Hernández-Baz, CPFHB, (Semarnat/CitesS/ CP-0026-Ver/05)

Leucotmemis pardimacula is found along the lowlands of the western slopes of Jalisco and Sinaloa, in the Colima region where it flies up to $600 \mathrm{~m}$, and in Guerrero where it can reach $900 \mathrm{~m}$. Even though the species was previously considered endemic from Mexico, in 2004 a male was collected in Chinandega, Nicaragua between the San Cristobal and Choco volcanoes at $696 \mathrm{~m}$ in an area of dry tropical forest with scattered coffee plantations. This report expands the known distribution of the species south to Central America by over 2,000 kilometers but still in a regions related to the Pacific slopes (Figure 2).

According to our field observations, the species flies at night and is attracted to mercury vapor lights. Specimens have been collected in May, July, August and October, suggesting that it could be bivoltine. Even though we now know that the distribution is broader than previously known, we still consider L. pardimacula a rare species with unknown biology.

Conservation. After analyzing the available information with the method to evaluate species vulnerability established by Hernández-Baz (2012) and determining conservation priorities, we feel that L. pardalimacula should be considered a 


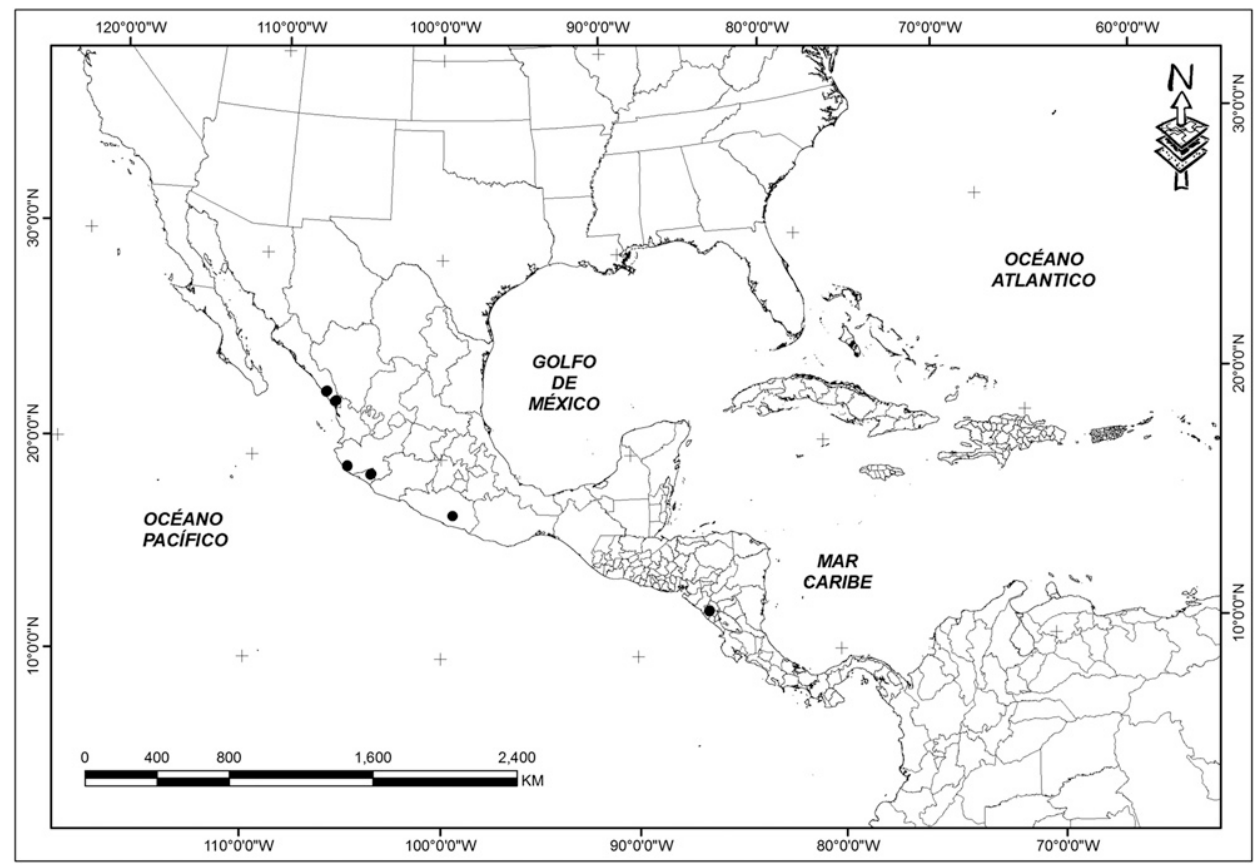

Figure 2. Leucotmemis pardalimacula distribution in the Americas. Dots represent all known localities gathered from database "Polilla", annex to the Semarnat/Cites/CP-0026-Ver/05, México (CPFHB) Lepidoptera collection, Xalapa, Veracruz, Mexico.

"threatened" species because of its limited geographic distribution and the low frequency with which it has been collected. Determining the host plants of this species will be important in any effort for conservation of this moth.

As important as considering L. pardalimacula a protected species, it is also relevant to encourage immediate fulfillment of the current legislation in order to protect the diverse ecosystems where vulnerable species live. The inclusion of Lepidoptera species for protection will not necessarily ensure protection if we do not protect the ecosystems where they are found.

Our knowledge on geographical distribution of the wasp moths, mainly Euchromiina, in Mexico and the Americas is very incomplete; this should prompt researchers to promote long-term collecting efforts within the multiple ecological regions of the country and on the continent. Moreover, increasing our biogeographical knowledge and understanding will also allow us to make better and more accurate decisions in order to preserve vulnerable species (Hernández-Baz 2012).

\section{ACKNOWLEDGMENT}

We would like to thank the curators that kindly allowed us the review the collections under their care: María E. Díaz-Batres (Museo Historia Natural Ciudad de México, MHNCM), Enrique González Soriano de la Colección Nacional de Insectos, Instituto de Biología, UNAM (CNIIBUNAM), Martin Honey Natural History Museum, London, U.K. (BMNH); Jorge León-Cortes from Colegio de la Frontera 
Sur Collection, Unidad San Cristobal de las Casas (ECO-SC-E). Thanks also to

William Hale and Andrea C. González for proof reading of earlier manuscripts.

\section{Literature Cited}

Bisby F. A., Y. R. Roskov, T. M. Orrell, D. Nicolson, L. E. Paglinawan, N. Bailly, P. M. Kirk, T. Bourgoin, G. Baillargeon \& D. Ouvrard. 2011. Species 2000 \& ITIS Catalogue of Life: 2011 Annual Checklist. Reading, UK. Available from http://www.catalogueoflife.org/annualchecklist/2011/ search/all/key/leucotmemis/match/1 (accessed 19 November 2013)

Butler, A. G. 1876. Notes on the Lepidoptera of the family Zygaenidae, with descriptions of new genera and species. The Journal of the Linnean Society of London 12:342-407.

Clemens, B. 1961. Contributions to American Lepidopterology. Proceedings of the Academy of Natural Sciences of Philadelphia 12:545.

Danielsen, F. \& C. G. Treadaway. 2004. Priority conservation areas for butterflies (Lepidoptera: Rhopalocera) in the Philippine islands. Animal Conservation 7:79--92.

Draudt, M. 1916. Syntomidae, pp. 33-230. In: A. Seitz (Ed.). Die Gross-Schmetterlinge der Erde. II. Abteilung: Die Gross-Schmetterlinge des Amerikanischen Faunengebietes, 6 Band, Die Amerikanischen Spinner und Schwärrmer. Alfred Kernen, Stuttgart, 497 pp.

Druce, H. 1884. Zygaenidae, pp. 1-72. In: F. Godman, \& O. Salvin (Eds.). Biología Centrali-Americana. Insecta, Lepidoptera-Heterocera, Volumen I Porter, London, England, $490 \mathrm{pp}$.

Dyar, H. G. 1927. Ten new Lepidoptera from Mexico. The Pan Pacific Entomlogist 4:7-10.

ESRI. 1998. Introduction to Arc View. GIS 3.2. Environmental Systems Reseach Institute, Inc. USA.

Hampson, G. F. 1898. Catalogue of the Lepidoptera Phalaenae in the British Museum, vol. I: Catalogue of the Syntomidae in the Collection of the British Museum. British Museum Natural History, London, $559 \mathrm{pp}$.

Heppner, J. B. 1991. Faunal regions and the diversity of Lepidoptera. Tropical Lepidoptera 2 (Supplement 1):1-85.

Heppner, J. B. 2002. Mexican Lepidoptera biodiversity. Insecta Mundi 16:171-190.

Hernández-Baz, F. 1992. Catálogo de los Ctenuchidae (Insecta: Lepidoptera: Heterocera) de México. Boletín Sociedad Mexicana de Lepidopterología (n.s.) 2:19-47.

Hernández-Baz, F. 2008. Mariposas de la familia Arctiidae de Aguascalientes, México, pp. 130-131. In: H. Avila, E. D. Melgarejo \& A. A. Cruz (Eds.), La Biodiversidad de Aguascalientes, Estudio de Estado. Conabio, Instituto del Medio Ambiente del Estado de Aguascalientes, Universidad Autónoma de Aguascalientes, México, 389 pp.

Hernández-Baz, F. 2009. Mariposas Arctiidae, pp. 109-112, 409-410. In: G. Ceballos, R. List, G. Garduño, C. R. López, M. J. Muñozcano-Quintana, E. Collado \& J. E. San Román (Eds.). La diversidad biológica del estado de México. Estudio de Estado. Conabio \& Gobierno del Estado de México, México, 530 pp.

Hernández-Baz, F. 2010. Arctiidae: Palomillas nocturnas, pp. 245-246. In: R. Durán, \& M. Méndez (Eds.). Biodiversidad y Desarrollo Humano en Yucatán, CICY, RPD-FMAM, Conabio, Seduma, México, $491 \mathrm{pp}$.

Hernández-Baz, F. 2011a. Palomillas nocturnas Arctiidae, pp. 197-201. In: C. Pozo (Ed.), Riqueza Biológica de Quintana Roo. Un análisis para su conservación. Tomo 2. Colegio de la Frontera Sur, Conabio, Gobierno del Estado de Quintana Roo, México, 271 pp.

Hernández-Baz, F. 2011b. Palomillas tigre (Insecta: Lepidoptera: Arctiidae), pp. 355-360. In: A. Cruz Aragón (Ed.). La biodiversidad en Veracruz: Estudio de estado, Vol. 2. Conabio, Gobierno del estado de Veracruz, Universidad Veracruzana, Instituto de Ecología, A.C., México, 650 pp.

Hernández-Baz, F. 2012. Biogeografia y conservación de las polillas avispa de México (Lepidoptera: Erebidae: Arctniidae Ctenuchina y Euchromiina). Editorial Académica Española, Saarbrücken, Deutschland, $328 \mathrm{pp}$.

Hernández-Baz, F. 2013. Mariposas tigre (Arctiidae), pp. 66-70, 227-231. In: A. Cruz Aragón, E. D. Melgarejo, F. Camacho R., K. C. Nálera C. (Eds.). La biodiversidad de Chiapas: estudio de estado. Comisión para el Conocimiento y Uso de la Biodiversidad y Gobierno del estado de Chiapas, México, 435 pp.

Hernández-Baz, F. \& A.C. Bailey. 2006. Los ctenuchinae (Insecta: Lepidoptera: Arctiidae) de la República de Guatemala: Una síntesis preliminar, pp. 403-413. In: E. Cano (Ed.). La Biodiversidad de Guatemala. Universidad del Valle de Guatemala. CONCYT, Guatemala, 649 pp. 
Hernández-Baz, F., R. Coates, J. A. Teston \& J. M. González. 2013. Scena propylea (Druce, 1894) (Lepidoptera: Erebidae: Arctiinae: Euchromiina) an endemic species of Mexico. Neotropical Entomology 42:246-251.

Hernández-Baz, F., J. M. González \& P. Tamez-Guerra. 2012a. Geographical distribution of Apeplopoda mecrida (Druce, 1889) (Erebidae: Arctiinae: Arctiini: Euchromiina) with notes about its natural history. Journal of the Lepidopterists' Society 66:225-229.

Hernández-Baz, F., J. M. González \& S. B. Vinson. 2012b. Ecology and Conservation of Coreura albicosta Draudt, 1916 (Lepidoptera: Erebidae: Arctiinae: Ctenuchina), an endemic species of Mexico. Southwestern Entomologist 37(3):369-378.

Herrich-Schäffer, G. A. W. 1854. Sammlung neuer order wenig bekannter aussereuropäischer Schmetterlinge. Vol. 1. G. J. Manz, Regensburg, 394 pp.

INEGI (Instituto Nacional de Geografía e Informática). 2012. Carta topográfica de México 1:250 000. Instituto Nacional de Estadística, Geografía e Informática, México.

Lafontaine, J. D. \& M. Fibiger. 2006. Revised higher classification of the Noctuoidea (Lepidoptera). The Canadian Entomologist 138:610-635.

Lafontaine, J. D. \& B. C. Schmidt. 2010. Annotated check list of the Noctuoidea (Insecta, Lepidoptera) of North America north of Mexico. Zookeys 40:1-239.

Myers, N., R. A. Mittermeier, C. G. Mittermeier, A. B. Da Fonseca G. \& J. Kent. 2000. Biodiversity hotspots for conservation priorities. Nature 403:853-858.

Peterson, A. T., O. A. Flores-Villela, L. S. León-Paniagua, J. E. Llorente-Bousquets, A. Luis-Martínez, G. Navarro-Siguenza, M. G. Torres-Chávez \& I. Vargas-Fernández. 1993. Conservation priorities in México: moving up in the World. Biodiversity Letters 1:33-38.

Semarnat. 2010. Norma Oficial Mexicana NOM-059-Ecol-2001, Protección Ambiental-Especies nativas de México de flora y fauna silvestres-categorías de riesgo y especificaciones para su inclusión, exclusión o cambio-Lista de especies en riesgo. Diario Oficial de la Federación, México. $84 \mathrm{pp}$.

Simmons, R. B, S. J. Weller \& S. J. Johnson. 2012. The evolution of androconia in mimetic tiger moths (Noctuoidea: Erebidae: Arctiinae: Ctenuchina and Euchromiina). Annals of the Entomological Society of America 105:804-816.

Weller, S. J., R. B. Simmons, R. Boada \& W. E. Conner. 2000. Abdominal modifications occurring in wasp mimics of the Ctenuchine Euchromiine clade (Lepidoptera: Arctiidae). Annals of the Entomological Society of America 93:920-928.

Weller, S. J, M. DaCosta, R. Simmons, K. Dittmar \& M. Whiting. 2009. Evolution and taxonomic confusion in Arctiidae, pp. 11-30. In: W. W. Conner (Ed.). Tiger moths and woolly bears: Behavior, Ecology, and Evolution of the Arctiidae. Oxford University Press, Oxford, 328 pp.

Received 26 Feb 2014; Accepted 4 Sep 2014 by P. T. Oboyski; Publication date 3 Nov 2014 
Copyright of Pan-Pacific Entomologist is the property of Pacific Coast Entomological Society, in cooperation with the California Academy of Sciences and its content may not be copied or emailed to multiple sites or posted to a listserv without the copyright holder's express written permission. However, users may print, download, or email articles for individual use. 